\title{
The Study of Hospital Archives in Preserving the Memories of Covid-19 Patients
}

\author{
$1^{\text {st }}$ Lolytasari Lolytasari $^{1}, 2^{\text {nd }}$ Lili Wenny Sudria ${ }^{2}, 3^{\text {rd }}$ Budi Sulistiono $^{3}, 4^{\text {th }}$ Evi Nurmiati $^{4}$ \\ \{lolytasari@uinjkt.ac.id ${ }^{1}$, weeny@uinjkt.ac.id², budi@uinjkt.ac.id³, evinurmiati@uinjkt.ac.id $\left.{ }^{4}\right\}$ \\ UIN Syarif Hidayatullah Jakarta ${ }^{1,2,3,4}$
}

\begin{abstract}
This article focuses on examining the role of hospital archivists in managing the memory of patients who are facing some challenges against the Covid-19 disease which they are suffering from. This pandemic is a non-natural disaster occurred in every country; therefore, it will give a historically valuable archives. The benefit of this research is that it contributes to enriching the scientific treasures of medical information and it can be a reference for academics and archival practitioners in managing medical information. The result of this study found that hospital archivists attempted to document patient health records in the form of medical records and carried out oral history, describing experiences through interviews with Covid-19 patients in recorded form. This memory is a historical journey of the patient that is documented and recorded and it can be used as a primary historical source. In conclusion, the more recorded data of the patient is the faster medical staff will deal with Covid-19 patients.
\end{abstract}

Keywords: oral archive, Covid-19, medical record.

\section{Introduction}

Covid-19 is a worldwide pandemic problem and Indonesia has confirmed 3.607.863 infected cases and it was recorded that on August 2, 69.645 .812 vaccines were given as a preventive measure[1]. Various countries have made effort to eradicate the Covid-19 pandemic, as did the United Kingdom through the National Institute for Health Research which has conducted research on 3.286 patients who have covid-19 disease. The results of the NIHR research are expected to help doctors dealing with Covid-19. The problem raised by the NIHR is what are the causes and how long can the Covid-19 disease be overcome? [2]. Mohd Amin [et.al] confirmed that the hospital is a place where the patient's life is related to his health. A good hospital depends on having professional doctors and nurses as well as good facilities and infrastructure. In recording the patient's disease diagnosis is strongly supported by the recording of medical records[3].

In general, the person in charge of managing archives in each institution is an archivist who has competence in compiling, retaining and saving archives. So the hospital archive manager is the hospital manager or medical records officer. Medical records as a means of tracking patient treatment are very important for hospitals. The benefit of documenting medical records are as material for decision making, education and research. On the other hand, if the medical record is incomplete it will harm the patient by re-observing the patient's disease. Therefore, medical records become a vital archive for patients and hospitals. This can 
be seen from the research conducted by Savani et.al (2016) on 16 hospitals at Mazandaran University of Medical Sciences (MazUMS)[4].

Improving the recording of patients' illnesses in medical records in Indonesia has started since the issuance of the Decree of the Minister of Health of the Republic of Indonesia No.031/Birhub/1972 concerning hospital planning and maintenance which obliges every hospital to manage medical recording, reporting and hospital statistics. The implementation of this decision is supported by the Fatwa of the Indonesian Doctors Association (IDI) in its Decree No.315/PB/A.4/88 which emphasizes that the practice of the medical profession is obliged to carry out medical records not only for doctors who work in hospitals also doctors in private practice. [5] Then the development of information technology was added after the postpandemic, the government recommended that every hospital provide electronic medical records as health services innovation.[6] The purpose of this study was to analyze the memory preservation of patients in hospitals infected with covid-19 which was explicitly stated in medical records.

\section{Methodology}

This study describes the recording of the experiences of Covid-19 patients who were treated at Syarif Hidayatullah Hospital. The method used qualitative aims to obtain a complete picture of a matter according to the view of the human being studied.[24] Tools in data collection using a list of questions, forms and notes as well as observations. Data collection techniques were carried out through primary and secondary data, namely primary data sources taken directly and collected by observation and interviews with hospital manager and medical records officers who handle files and case files of covid-19 patients, as well as nurses in the archives and files section. Secondary data was collected from existing sources such as records and documentation, journal and hospital webs through observation and collection of existing documents.

\section{Result and Discussion}

\subsection{Hospital Archive}

The word archive as it is used today comes from the Dutch archive which means archive. The meaning of archive in Dutch was adopted by Indonesia and translated by Sulistyo Basuki into two meanings, dynamics archief which means dynamic archive and statistics archief which means static archive[5]. Dynamisch archive can be interpreted as a record which means

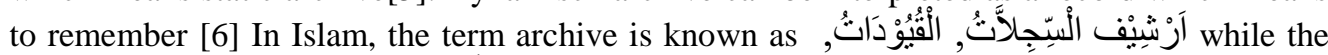

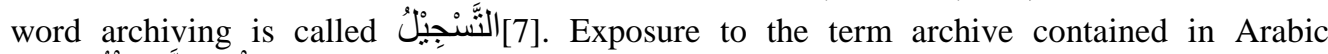

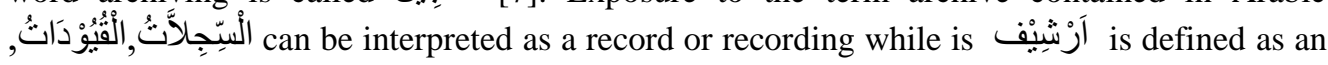
archive in general[8]. In addition, during the Islamic period during the leadership of Abd alMalik and al-Walid, the term diwan was known, namely public administration. Diwan comes from the native Persian language which was the first administrative term used in Persia[9]. 
Thus the archive can be said as a long journey of documents stored in the repository on which history relies[10].

One repository that will become a historical reference is a document or archive contained in the Hospital. Refer Azrul Azwar (2015), the understanding of the hospital is not only a hospital that heals the sick people but currently meaning to developing function as a center for health, education and research[11]. Hospital business functions are seen as health services to the community which will produce health and medical records. In practice, hospital archives attached to patients according to Michael Roper in his book Managing Hospital Records include: patient personal data including referral data from hospitals, case notes containing the results of patient diagnoses with doctors and nurses starting from the results of temperature, blood pressure, records operations and various forms of treatment, special records such as XRay films, specimens from patients such as plasma, serum bodily fluids, swabs, wet tissue or whole them for pathological examination and prescriptions and administration[11].

\subsubsection{Archiving in Islam}

The command regarding archiving is found in Surah Al-Baqarah: 282, in the word of Allah SWT فَلْيَنُبْنْ which means: "You should write it down." Tafsir Al-Quthubi explains that some scholars say the command in this verse is to write down debts and receivables is obligatory, but the real meaning is the command to write and testify. Because writing without being witnessed cannot be a strong proof. Then there are also those who argue that the writing order is so that neither party forgets about the transaction[12].

Al-Misbah further elaborates that the verse of QS 2:282 above is the longest verse in the Qur'an which is known by scholars as the verse on debts or the verse of alMudayanah. This paragraph emphasizes the obligation to write down debts and receivables, no matter how small the amount is accompanied by a stipulation of time and testify before a trusted third party. The third party here according to Quraish Shihab is a notary[13]. In accordance with its characteristics, the writing of debts and receivables over time can become an authentic document, and a notary acts as savior of the community who requires evidence or legal documents in the form of an authentic deed recognized by the state as proof of ownership[14].

The Ministry of Religion in its interpretation adds that in the verse of QS 2:282 where Allah commands believers that debt and receivable transactions carried out by muslims must be recorded accompanied by written evidence written by a clerk and witnesses carried out by two male and two female witnesses. The contents of the agreement in written evidence should be agreed upon by both parties[15].

\subsubsection{Memory Become Archive}

Memory is absolute, while history can only conceive the relative[16]. The process of recording that cannot be forgotten is an activity that produces a memory that is embedded in memory. Hartati et.al stated that there are 3 stages in memory, namely: (a) the encoding stage or the entry of messages into memory, (b) storing or maintaining, is called the storage stage and finally (c) retrieves the memory that has been stored. This is known as the retrieval or retrieval stage. Memory is divided into 2 types, namely (a) short-term memory, namely remembering information only for a few seconds, and this memory involves three stages, namely encoding, storing and retrieval and (b) long-term memory, namely process of forgetting at intervals of minutes, hours and weeks[17]. This long term 
memory process will become an unforgettable history if it is stored and archived properly. Theorically, Bradsher states that archives stored can study the past which will be used as material for knowledge for now and in the future[18].

Archives are related to various transaction activities in the community and are closely related to human services. Evidence of service in the medical world is referred to as a medical record which is not only a memory reminder but also as a solution to treatment strategies and patient care. In addition, it can be used as evidence, learning resources, education and research in health and medicine.

\subsection{Preserving The Memories Archive of Covid-19 Patien}

As described earlier, filling in hospitals cannot be separated from the role of managers in each unit in the hospital. Based on the results of interviews that hospital archives created by hospitals are stored in each work unit. The goal is to make it easier for archive creators to search and compile alphabetically, and numerically. The memory of the hospital archives that are collected will make the identity and history of the hospital's development and accountability. The questions raised by O'toole and Cox recognize that need for preservation and preservation of archives is the lifeblood of archival institutions. The term preservation is used to describe the protection of archival collections where no physical and technological or chemical treatments are carried out. Preservation is the sum total of processes and tasks performed to protect records of any kind from damage. Preservation action policies need to be established to maintain an adequate environment and ensure archives are safe from harm[19].

By implication memory is not knowledge but a real awareness. To prove it, documents are needed as evidence of past knowledge. Management of this knowledge is a memory saved by archivist as material to expand knowledge, social identity and for historians, memory is an interest in tracing archives as evidence of a different past journey from the present[20].

Historically it can be said that at that time it was not easy for hospitals to accept Covid-19 patients. This is because hospital is not ready in various ways, especially in terms of facilities and infrastructure and the availability of medical personal to handle these special patients. The current capability of the hospital is clas $\mathrm{C}$, so the new hospital is able to provide limited specialist medical services. Services for Covid-19 patients, Syarif Hidayatullah Hospital was started on March 18, 2021. This hospital in addition to serving the wider community also specifically serves students of UIN Syarif Hidayatullah Jakarta both from undergraduate to doctoral program as well as lectures/employes.

If we refer to Azrul Azwar's opinion that at least Class C Hospital services there are four specialist services, namely internal medicine services, outside services, child health services and obstetrics and gynecology services[11]. Referring to the hospital website, there are two categories of services provided, namely inpatient and outpatient and there is an isolation treatment room, namely a room dedicated to patients with infectious diseases, separated from patients who are not infected[22].

Handling Covid-19 patients, according to the results of the interview, the informant stated that in its implementation it followed the policy of the Syarif Hidayatullah Hospital by carrying out several procedures, namely by screening the patient's vital signs, physical examination of the patient and medical supporting examination of the patient and medical supporting examinations in the form of blood laboratory examinations, sweb PCR, and chest radiology. If clinically symptoms of fever, cough, shortness of breath and positive PCR Sweb results are found, the patient is treated in a special isolation room for Covid-19 patients. The patient data will be recorded through the medical record. Bisatyo Mardjikoen stated that 
writing in medical records has the aim of documenting all the results of interviews, physical examinations, supporting examination and therapy that the patient undergoes. On the hand, medical records have the benefit of being a tool for communication documents between health practitioners who treat patients, whether doctors, nurses, radiographers, lab analyzers, physiotherapists, pharmacists and as reference materials for teaching general practitioners and specialists[23]. So that it can be said that medical records are evidence of a doctor in dealing with each patient to avoid misdiagnosis and planning medical treatment.

When this research took place, the hospital was in lockdown condition, so researchers could not see directly the implementation of the medical record storage carried out by the medical record manager. Syarif Hidayatullah Hospital in saving its medical records through two media namely paper media and electronic media. Important components of recorded patient data include age, gender, education, religion, patient origin, occupation and marital status. These data will be questioned when registering as a new patient and for old patients only the hospital card that has been recorded previously will be asked. Those Hospital Archive preservation is carried out in accordance with the procedures for maintaining/storing medical record files for Covid-19 patients in accordance with the circular letter of the Central Executive Board of the Indonesian Association of Medical Recorders and Health Information Professionals (PORMIKI) No.HM.01.01/002/III/2020 dated March 25, 2020, the medical record file during the treatment period is always in the nurse station room and is not allowed to be brought into the patient care room.

As the researcher explained above, could not show the placement of medical records, because the medical record room during the study was prohibited from being observed. The Ministry of Health provides an example of placing medical records as shown in Figure 1, reviewing medical records in a hospital[29].

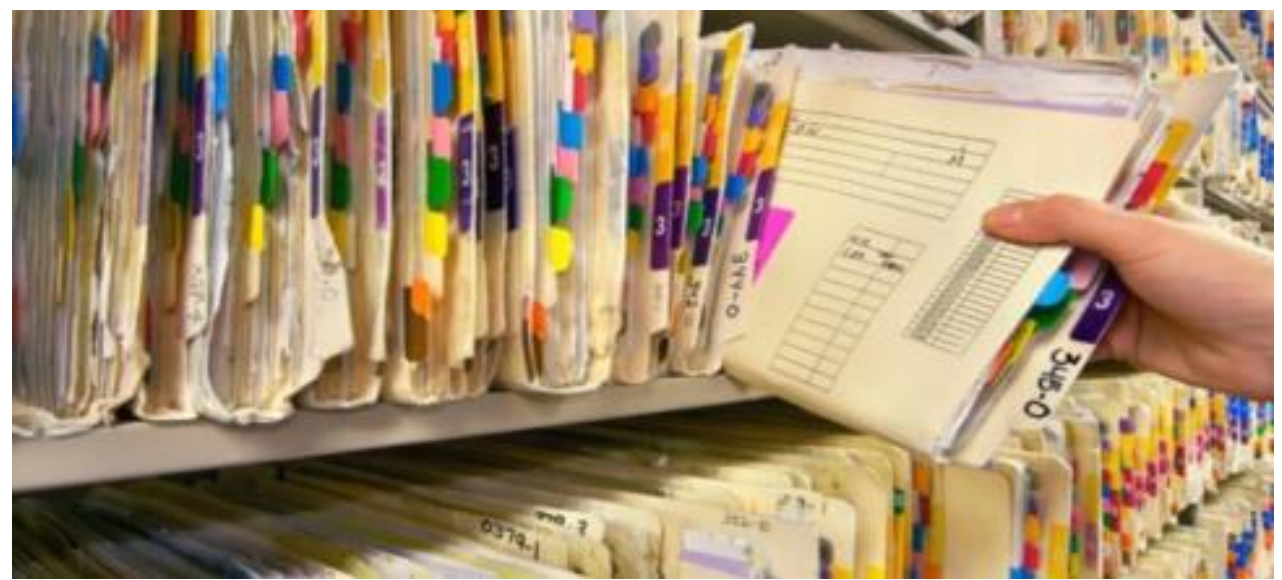

Fig. 1. Adopted from Medical Record Teaching Materials and Health Information (RMIK). 
Another example that can be applied to hospitals is writing medical records for covid-19 patients who died. The Kenya government has provided standard guidelines for writing medical records for covid patients who died, as shown in Figure 2[30].

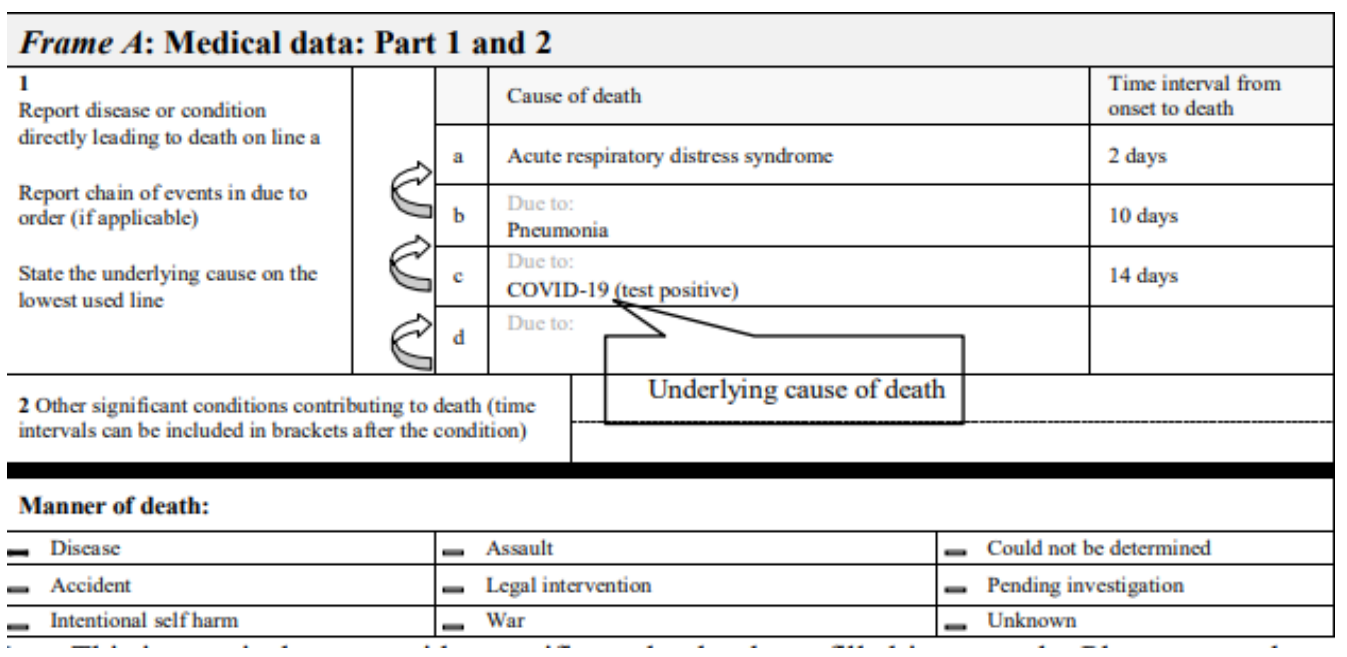

Fig. 2. Adopted from Standard Operating Procedures in Handling of Health Records and Information Management During the Covid-19 Pandemic, 2020.

In order for the cause of death to be recorded, the form should be clarified whether it was caused by respiratory infections, the common cold to serious illnesses such as Middle East Respiratory Syndrome (MERS) and Severe Acute Respiratory Syndrome (SASRS)[31]. This data collection is very important to find out how far the impact of covid-19 on the patient's immune system.

As it is known that archives will be kept based on historical, legal, financial and evidence values. Therefore, the storage period for medical records as stated in the regulation of Minister of Health in 2008 is kept for at least five years from the last date the patient was treated. After that it can be destroyed except for the summary of discharge and approval of medical action, this must be kept for ten years from the date the summary wa made, kept by the medical record officer[22]. If we refer to the provision of the National Archives of the Republic of Indonesia as a national archiving state, the covid-19 pandemic archive is a static archive that cannot be destroyed except after going through an assessment process between the authoring institution and the national archive institution. This is in accordance with the mandate of the archival law that every record of national activities or events must be preserved[32]. 


\section{Conclusions}

The conclusion that can be given in this study is that the more managed memory is in the form of archives, the more written memory can be evidence. Medical record managers have a big role in making the history administration which will make the hospital a source of medical history. Hospital records managers must collect knowledge that has existed in the hospital by collecting all related for future purposes.

Acknowledgments. This research was conducted during the PPKM (Enforcement of Community Activity Limitations) where there was a government recommendation to limit attendance in various sectors of the place. On the other hand, the medical record officer is indicated to be Covid, so the author is limited to observing directly in the field. However, this research data was carried out in collaboration with the hospital management in answering research questions sent via e-mail. Hopefully this research can be useful for hospital archive managers and medical records and can be used as a basis for researchers to follow up.

\section{References}

[1] World Health Organization., "Global Indonesia," World Health Organization., 2021. [Online]. Available: https://covid19.who.int/region/searo/country/id.

[2] B. Raman et al., "Living with COVID-19 Second Review," Mindfulness (N. Y)., vol. 6, no. 4, pp. 334-347, 2021.

[3] N. A. M. Amin et al., "Role of Medical Records Management Practice in Improving Decision Making in University Hospital," Int. J. Acad. Res. Bus. Soc. Sci., vol. 10, no. 11, 2020.

[4] B. M. Saravi et al., "Documentation of medical records in hospitals of Mazandaran University Of Medical Sciences in 2014: A quantitative study," Acta Inform. Medica, vol. 24, no. 3, pp. 202-205, 2016.

[5] M. Jusuf Hanafiah; Amri Amir., Etika Kedokteran dan Hukum Kesehatan. Jakarta: EGC, 1999.

[6] Kementerian Kesehatan., "Panduan Teknis Pelayanan Rumah Sakit Pada Masa Adaptasi Kebiasaan Baru.” Direktorat Pelayanan Kesehatan Rujukan Direktorat Jenderal Pelayanan Kesehatan Kementerian Kesehatan., Jakarta, 2020.

[7] Sulistyo-Basuki, Kamus Istilah Kearsipan. Yogyakarta: Kanisius, 2005.

[8] G. Yeo, Records Information and Data; Exploring the Role of Records-Keeping in an Information Culture. London: Facet Publishing, 2018.

[9] A. W. M. F. Munawwir, Al-Munawwir: Kamus Indonesia-Arab. Surabaya: Pustaka Progressif, 2007.

[10] Lolytasari, Pengelolaan Arsip Keagamaan pada Masjid Bersejarah di Indonesia. Jakarta: Adabia Press, 2020.

[11] E. Posner, "Archives in Medieval Islam," Am. Arch., vol. 35, no. 3-4, pp. 291-316, 2015.

[12] K. Müller, "Between Lived and Archived Memory: How Digital Archives Can Tell History," Digithum, vol. 0, no. 19, p. 11, 2017.

[13] Azrul Azwar, Pengantar Administrasi Kesehatan. Jakarta: Bina Rupa Aksara, 2015.

[14] M.; L. M. Roper, A Training Programme Managing Hospital Records. United Kingdom: International Records Management Trust, 1999.

[15] S. I. Al-Qurthubi, Tafsir Al-Qurthubi Jilid 3. Jakarta: Buku Islam Rahmatan, 2007.

[16] M. Q. Shihab, Tafsir Al-Misbah; Pesan, Kesan dan Keserasian Al-Qur'an. Jakarta: Lentera Hati, 2000 .

[17] R. Usman, "Kewenangan Notaris dalam Membuat Surat Kuasa Membebankan Hak Tanggungan dengan Akta," J. Legis. Indones., vol. 10, no. 2, pp. 1-15, 2018. 
[18] Kementerian Agama., Al-Qur'an dan Tafsirnya (Edisi yang Disempurnakan). Jakarta: Kementerian Agama Republik Indonesia, 2011.

[19] P. Nora, "Between Memory and History: Les Lieux de Memoire (The place of Memory)," Spring, vol. Spring, no. 26, pp. 7-24, 1989.

[20] N. Z. N. A. S. A. Hartati, Islam dan Psikologi. Jakarta: UIN Jakarta Press, 2003.

[21] J. G. Bradsher, "An Introduction to Archives," in Managing Archives and Archival Institutions, James Gregory Bradsher, Ed. London: Mansell Publishing Limited, 1991.

[22] Kementerian Kesehatan., "Peraturan Menteri Kesehatan Republik Indonesia Nomor 269/MENKES/PER/III/2008 tentang Rekam Medis,” vol. 2008. p. 7, 2008.

[23] Konsil Kedokteran Indonesia., "Manual Rekam Medis - Konsil Kedokteran Indonesia." Konsil Kedokteran Indonesia., Jakarta, 2006.

[24] Sulistyo Basuki, Metode Penelitian. Jakarta: Wedatama Widya Sastra Fakultas Ilmu Pengetahuan Budaya Universitas Indonesia, 2006.

[25] L. A. Millar, Archive Principles and Practices. London: Facet Publishing, 2017.

[26] B. Brothman, "The past that archives keep: Memory, history, and the preservation of archival records," Archivaria, vol. 51, no. 1, pp. 48-80, 2001.

[27] Rumah Sakit Syarif Hidayatullah, "Layanan Rumah Sakit Syarif Hidayatullah," Rumah Sakit Syarif Hidayatullah, 2021. [Online]. Available: https://www.rssyarifhidayatullah.com/layanan/rawatinap/ruang-perawatan-isolasi.

[28] M. M. F. R. A. F. N. A. Bisatyo, Komunikasi Efektif Dokter-Pasien. Jakarta: UIN Jakarta Press, 2015.

[29] Endang Triyanti; Imelda Retna Weningsih., Bahan Ajar Rekam Medis dan Informasi 